くことになるが，CAIで実施されているディスプレイの 利用形態は，乙のような汎用的なシステムの中でもひと つのひな形として継承されてゆくととになると考えられ る.

(昭和 47 年 8 月 4 日受付)

〔参考 文 献〕

1）館山市教育有線テレビ放送システム，芝電気資料 (1972.4)

2) 平野ほか: 小形計算機に上る CAI の關発, 日立評諭, 53，3 (1971) 68-73

3）谷，山根ほか：テレビジョン形式個人用 CAI 装置の番組試作と
実験, 電子通信学会教育技術研究会 (1970.11)

4) 中村ほか: CAIシステムの機能仕栐について, 電気通信学会教育 技術研究会資料 (1972.6)

5) D. Alpert: Advances in Computer-based Education: A Progrees Report on the PLATO Program, CERL Report X-10, (July, 1969) Univ. of Illinois.

6) 安東: 画像データ伝送による新しい放送, 昭46年電気牭学会連大 予, No. 146

7) J. Volk: The Reston, Virginia, Test of the MITRE Corporation's Interactive Television Systems (May, 1971) MITRE Co., MTP-352

8) K. Stetten: TICCIT-A Delivery System Design for Mass Utilization (Oct. 1971) MITRE Co., M71-56

特集 画像エレクトロニクス

\title{
2-4 画像情報伝送システム
}

\section{1. ま え がき}

われわれが外界から受ける情報のうち，情報量の最む 多いものは視覚情報で，こ机につぐものが聴覚情報であ るといわれている1。，それにもかかわらず，通信サービ スとして広く普及したのは聴覚通信であり, 視覚通信之 してはテレビ放送以外には，わずかに専用線を用いるフ アクシミリ位しか実用に供せられていない，視覚通信の 発展が遅れたのは，視覚通信に対する必要がなかったた めというよりは，技術的，経済的な制約にもとづく実現 困難性に，その主な原因があるあのと思われる。

広带域情報を取扱う視覚通信の経済情汇対し, 最む大 きな関係をむつのは伝送路価格であり，これが視覚通信 の発展をはばんでいたのであるが，最近における伝送技 術の進歩によって視覚通信を経済的に提供しうる見通し がたつようになってきた.また，国内あるいは国際間にお ける経済社会活動の活発化にともなって，いわゆる情報 革新が進み，画像通信に刘する要望が熾烈になってきて いる，その結果，近い将来に放送テレビ，専用線による ファクシミリ以外に, 各種の画像通信サービスが実施さ れる可能性が高まってきた。これらの新画像通信サービ ス項目はきわめて複雑多岐になるもの上考えられるが， 各サービス項目別にそれぞれ独立した通信システムを作 成することは非能率であり，また不経済でああるので， 統合できるむのはできるだけ統合して，すっきりとした

"2-4 Transmission System for Picture" by Toshi Minami (Musashino Electrical Communication Laboratory, Nippon Telegraph and Telephone Public Corporation, Tokyoj
日本電信電話公社 武蔵野電気通信研究所

南

敏

形の画像通信システムあるいは画像通信網を構成するこ とが望まれる。

特に伝送方式としては，通信サービスの種類が異なっ ていても，伝送される情報信号の性質が似ていれば，同 一の伝送路を通しててれらの情報を伝送できるわけで， この立場から伝送網を設計するととが重要となる。ここ ではまず，将来の画像通信サービスについて簡単な考察 を行ない，ついでそれらのサービスを提供するために用 いられる各種伝送方式について述べるとにする.

\section{2. 将来の画像通信サービス}

画像通信で取扱う画像情報をこの動きによって分類す ると, 静止画像と動画像に分けることができる. また静 止画像であってあ，ただ 1 枚の画像情報が得られれば良 い場合と，一連の静止画像をある時間間隔をおいて，つ ぎつぎに見る場合とがある。

動画像通信を代表するむのは, テレビ, テレビ電話, テレビ会議方式等で, 被写体は 3 次元動画像, 再現像は 3 次元ないし 2 次元の動画像である. 一方, 静止画像通 信を代表するファクシミリの場合, 情報は 1 枚のシート 状の紙に印刷または手書きされた原稿であり，階調を有 する場合もあるが，白黒 2 值だけの場合も多い，最近で は，ブックファクスに見られるように，厚い本や雑誌の 一部を電送できるような装置もできている，さらに進ん で，実物見本のような 3 次元静止画像を，レンズ系によ って 2 次元画像に変換し， 2 次元静止画像として電送し ようという要望す当然でてくるものと思われる，またス 
ライド，マイクロフィルム等に蓄積された情報を電送す る場合もある。

画像情報の蓄積は必ずしも光学的な形をとるものとは 限らず, 磁気テープ等に録画しておいて必要に応じて電 送し，受信側で画像を再生する方式が考光られる。また 画像以外の形で蓄積されている情報や，情報処理装置の 内部で処理された情報の出力を, 特別の変換装置によっ てテレビ信号あるいはファクシミリ信号に変換し，電送 する方式も検討されている.

つぎに，画像通信システムに㧍ける送信者と受信者に 着目して画像通信サービスを分類すると，特定の 2 点間 を結ぶ 1 対 1 の専用通信，特定多数の加入者に同一内容 の情報をセンターより供給する同報通信，不特定多数の 加入者を対象之する放送，不特定多数の加入者相互間で 情報の送受を行なう交換網を用いた公衆通信等に分ける ことができる．また，乙れらの応用として，公衆通信の 加入者がセンターを呼び出し，加入者からの要求にもと づいて所望の情報を得るような通信方式む考えられる．

以上の画像通信サービスを通信網の立場から分類し， 整理すると表 1 のようになる。乙のうちテレビ放送網, CATV 網については，本特集号のなかで別個に取扱わ れており,ファクシミリ伝送についても最近の本誌に紹 介があるので ${ }^{22}$ とれについては説明を省略することと し，とこではテレビ電話網を主体に画像情報伝送システ ムについて考察を進める。

\section{3. テレビ電話網による画像情報の伝送}

テレビ電話は対面通話の実現を目的としているが，そ の効用を高めるために, 簡単な文書の電送, 小グループ

表 1 各種サービスと通信網

\begin{tabular}{|c|c|c|c|c|}
\hline 通信網種別 & サービス項目 & \multicolumn{2}{|c|}{ 伝送媒体 } & 伝送方式 \\
\hline テレビ放送網 & テレビ放送 & 空 & 間 & 周波数分割 \\
\hline \multirow[t]{2}{*}{ C A T V網 } & テレビ放送 & \multicolumn{2}{|c|}{ 同軸ケーブル } & 周波数分割 \\
\hline & 静止画像放送 & \multicolumn{2}{|r|}{ " } & $\begin{array}{l}\text { 周波数夌割 } \\
\text { 十時分割 }\end{array}$ \\
\hline \multirow[t]{4}{*}{ テレビ電話網 } & \multirow{4}{*}{ 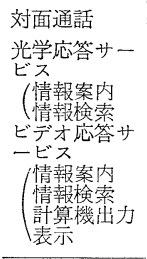 } & 加入者線 & 対ケーブル & ベースバンド \\
\hline & & \multirow[t]{3}{*}{ 中継線 } & 同軸ケーブル & $\begin{array}{l}\text { 周波数分割ま } \\
\text { た時分割 }\end{array}$ \\
\hline & & & $\begin{array}{l}\text { 空間(マイク } \\
\text { 波, 準ミリ } \\
\text { 泿) }\end{array}$ & $\begin{array}{l}\text { 周波数分割ま } \\
\text { た洔分割 }\end{array}$ \\
\hline & & & ミリ波導波管 & $\begin{array}{l}\text { 周波数分割 } \\
\text { +時分割 }\end{array}$ \\
\hline \multirow[t]{2}{*}{ 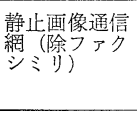 } & \multirow{2}{*}{ 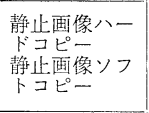 } & \multicolumn{2}{|c|}{ 加入者線 } & 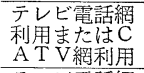 \\
\hline & & 中 & 継 線 & $\begin{array}{l}\text { テレビ電話網 } \\
\text { 利角 }\end{array}$ \\
\hline 網厂クシミリ & 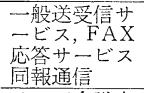 & \multicolumn{3}{|c|}{$\begin{array}{l}\text { 一般䨋話網 } \\
\text { 岕需域紊線網 }\} \text { 利用 } \\
\end{array}$} \\
\hline 專用回線網 & $\begin{array}{l}\text { 式, ぞ会議方 } \\
\text { 严他 }\end{array}$ & \multicolumn{3}{|c|}{ 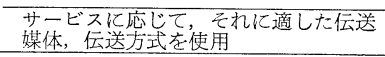 } \\
\hline
\end{tabular}

$924(42)$
による会議むできるととが望ましいとされており，信号 の帯域幅む1 $4 \mathrm{MHz}$ となっている. 電話と比較した場 合に，乙れは 250〜1,000 倍の周波数帯域が必要なとと を意味し，従来テレビ電話が普及しなかったのは，乙の 広帯域信号を伝送する費用がきわめて高かったためと考 えられる。

テレビ電話の各種伝送方式については，本誌に书いて 技術展望3)がなされて㧍り，また，テレビ信号の帯域圧 縮伝送方式についてもすでに詳細な報告(4) があるので, それらを参照しながら，ここでは主として経済性および 品質の点から見て各種方式を比較検討してみたい.

\section{1 加入者線伝送方式}

音声電話の場合，電話局から加入者までは，主配線盤 一き線ケーブル (2, 400 対程度の多対地下ケーブル) 一 配線ケーブル (100 対程度の小対架空ケーブル)一端子 箱一屋外線等によって接続が構成され，加入者ごとに 1 対ずつの心線が用いられている。

音声電話の場合には，数 $\mathrm{kHz}$ までの信号伝送ができ れば充分明瞭な通話ができるとされているが，その信号 を通す加入者ケーブル自体は数 $\mathrm{MHz}$ までの信号伝送を 可能とする潜在能力をすっている．乙の潜在能力を利用 すれば，対ケーブルを通してテレビ電話信号伝送が可能 となる，ただし，音声電話の場合にはケーブルの使用効 率を高めるため, 固定配線法, 連絡配線法, $\mathrm{CCP}$ 配線 法等の特別の配線法を用いて抢り，乙の影響で高周波伝 送特性が悪くなるので，テレビ電話のような高周波信号 を通ずる場合には，乙れら品質劣化要因を取除く必要が ある ${ }^{677)}$. 図 1 は固定配線法の説明図であるが，同図で 局線 No. 6 6 8 は 1 号柱と 2 号柱の両地点で引出されて いる. このため 1 号柱のそばの加入者が No. 6 の加入線 を用いたとすると， 2 号柱の所でマルチプル線が枝分れ しているため，乙こで信号の一部が反射し妨害となる. このマルチプル線のととをブリッジドタップと称してい るが，その長さが $30 \mathrm{~m}$ 以上になるとビデオ信号に対す る妨害が大きくなるので，乙れを取除く必要が生ずる.

伝送信号の形としては, ビデオ信号をそのままの形で 伝送するベースバンド伝送方式, 振幅変調等のアナログ

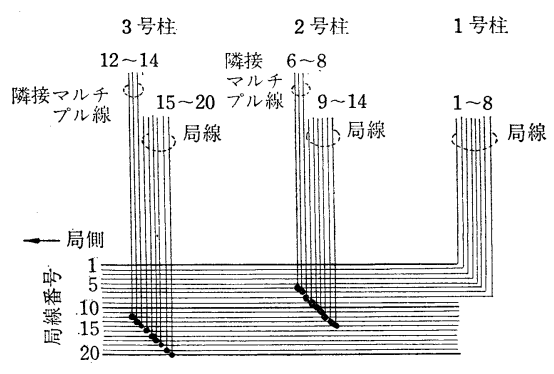

図 1 固定配線法 
表 2 加入者線伝送方式経費

\begin{tabular}{|c|c|c|c|}
\hline \multicolumn{2}{|c|}{ 項 目 ケーブル種別 } & $\begin{array}{l}0.4 \mathrm{~mm} \text { 市内紙ケ } \\
\text { ーブル }\end{array}$ & $\begin{array}{l}0.9 \mathrm{~mm} \text { 市外 PEF } \\
\text { ケーブル }\end{array}$ \\
\hline \multicolumn{2}{|c|}{$\begin{array}{c}\text { ケーブル価格相詨値 } \\
\text { (対 } \mathrm{km} \text { あたり) }\end{array}$} & 1 & 7 \\
\hline \multicolumn{2}{|r|}{$\begin{array}{c}\text { 中継器価格相対值 } \\
\text { (两方向) }\end{array}$} & 21 & 21 \\
\hline \multicolumn{2}{|c|}{$\begin{array}{c}\text { 中 継 間 隔 } \\
(1 \mathrm{MHz} \text { テレビ電話) }\end{array}$} & $1 \mathrm{~km}$ & $3 \mathrm{~km}$ \\
\hline \multirow{4}{*}{$\begin{array}{l}\text { 加 } \\
\text { 入 } \\
\text { 者 } \\
\text { あ } \\
\text { た } \\
\text { b } \\
\text { 平 } \\
\text { 均 } \\
\text { 経 } \\
\text { 費 }\end{array}$} & $\begin{array}{l}\text { 電話用ケーブル価 } \\
\text { 格 }(0.4 \mathrm{~mm} \text { ケ } \\
\text { ブル使用) }\end{array}$ & 1 対 $\times 2 \mathrm{~km} * \times 1=2$ & 1 対 $\times 2 \mathrm{~km} * \times 1=2$ \\
\hline & $\begin{array}{l}\text { ビデオ用ケーブル } \\
\text { 価格 }\end{array}$ & 2 対 $\times 2 \mathrm{~km} * \times 1=4$ & 2 対 $\times 2 \mathrm{~km} * \times 7=28$ \\
\hline & 中継器洒格 & 2 個 $\times 21=42$ & 2 個 $\times 21 \times \frac{1}{4}^{* *}=10.5$ \\
\hline & 総＼cjkstart経 & 48 & 40.5 \\
\hline
\end{tabular}

* 加入者線平均距離 $=2 \mathrm{~km}$

** 中継器数低減率

変調を用いる方式，PCM 等のディジタル変調を用いる 方式等がある. アナログにせよディジタルにせよ変調器 を用いる方式では変復調に費用がかかり，また変調によ り最高周波数が大きくなり漏話の影響を受けやすくなる ため, ベースバンド伝送方式が経済性，伝送品質の両面 から見て最も有利であると考元れている．ただしての 場合には, ビデオ信号の送受に各 1 対, 音声の伝送に 1 対合計 1 加入者あたり 3 対のケーブルが必要上なる.

加入者線伝送方式に抢いて伝送距離を制限するむのは 伝送損失と漏話である。伝送損失が一定值を越すと, 中 継器が捚入され損失が補償される．ケーブル心線径が太 くなるほご損失が減り，中継間隔はのびるがケーブル価 格は増大する. 表 2 はケーブル価格と中継器の相対価格 を示したものであるが，中継器洒格が比較的高価なので できるだけ損失の少ないケーブルを用いて中継器数を少 なくしたほうが，総合的に有利になるといえる。また， 電話に比して2桁以上の広带域信号を伝送しているにも かかわらず，価格は1桁程度の増加ですんでいることが わかる。

以上は既存の電話ケーブルを使用した場合の検討であ るが，現在このほかに画像用新形対ケーブルおよび超細 心同軸ケーブルの研究が進められている．後者はより広 帯域の信号伝送を目的としたあのである．加入者線路網 としては以上の電話形の通信網のほかに，CATV 網形 式のあのが考えられるが，テレビ電話の場合には，上り 扔よび下り方向の伝送路数が同数だけ必要で，一方向伝 送を主とする CATV 網ではトラフィック的に無理があ り，テレビ電話用としては不適当であると判断される.

\section{2 市内中継伝送方式および市外発着信回線用伝送} 方式

テレビ電話網構成は, 現在の電話網構成とほぼ同じ形 になることが想像される，図 2 は市内電話網構成，図 3

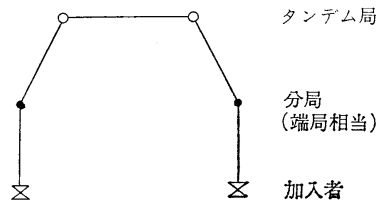

図 2 市内電話網構成

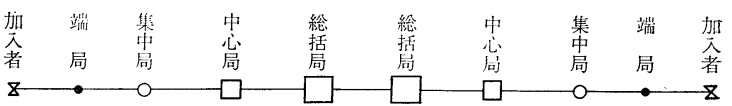

図 3 市外電話網構成

は市外電話網構成の概要で, 市内網の場合, 分局 (端局) 〜分局間距離は最大約 $30 \mathrm{~km}$ である. 市外電話網で, 端局と集中局の間が市外発着信回線であり, その平均距 離は約 $17 \mathrm{~km}$ である，短距離伝送用はベースバンド伝 送方式が最あ経済的であるが，中継数が増えると，熱雑 音, レベル変動, 伝送量, 周波数特性等の劣化が目立つ. 米国の例では, 市外発着信回線の場合, 片側で $100 \mathrm{kft}$, 全体で $200 \mathrm{kft}$ (市内中継線むこれに準じていると考えら れる）まではベースバンド伝送方式を採用している77. さらに距離がのびる場合は，次節で示す各種伝送方式の 適用が望ましいものと判断される。

\section{3 長距離市外中継伝送方式}

\section{(1) 最高伝送周波数}

図 3 亿示す集中局以上の区間に対しては多重伝送方式 が用いられる。乙れらの区間は平均距離が長く, 総括局 ～総括局間は平均約 $800 \mathrm{~km}$, 総括局〜中心局間は約 100 $\mathrm{km}$ ，中心局〜集中局間は約 $50 \mathrm{~km}$ である. したがって テレビ電話網全体の工事費のうち，乙の区間の伝送路工 事費が占める割合は 30～60\% にあ達し，その経済化は テレビ電話方式発展のため是非必要となる，幸い，伝送 路の年経費現価は大容量方式の出現とと屯に低下する傾 向にあり，その一例8 ${ }^{87}$ を図 4 亿示す。同図で $\mathrm{C}-4 \mathrm{M}$ 方 式之 C- $60 \mathrm{M}$ 方式を比較すると, 年経費現価は約 $1 / 5$ に 低下しているが，両方式の実用化の間には約 15 年の年 月を要しており，年経費現価は 5 年で $60 \%$ に，15 年で $35 \%$ に，15 年で 20\% 亿低下している. ての低減率が

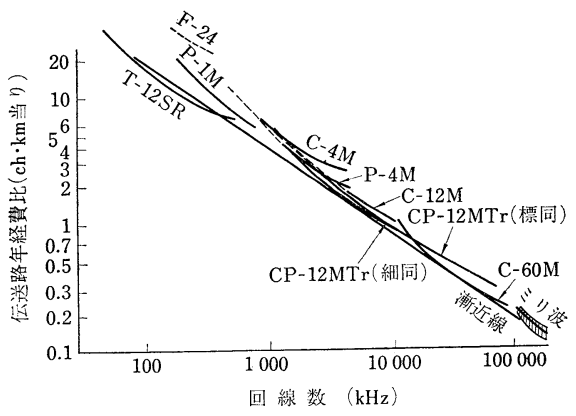

図 4 各種伝送方式の伝送路経費 
今後とも持続するという保証はないが，新方式の実現に より経済性が改善されることは間違いないであるう。

市外回線経費は端局価格と中継伝送路洒格に大別され さらに中継伝送路価格は伝送媒体価格と中継器価格に細 分できる、中継器洒格は使用される部品および単位距離 あたりに挿入される中継器数に比例するが, 部品の進歩 は中継器の性能を向上させると同時にその価格を低下さ せてきた. 中継器を増やし伝送媒体損失を補償ず机ば伝 送帯域幅を増やすととができるわけで，伝送方式の研究 はこの線に沿って伝送最高周波数をできるだけ大きくす る方向に進んでいる.

しかし，ある1つの伝送媒体が与えられた場合，いく らで屯高い周波数を伝送できるというわけではなく，各 伝送媒体固有の最高伝送周波数限界が存在する. 対ケ一 ブルの場合は漏話のために制限か課され, 周波数分割多 重伝送方式の場合には約 $400 \mathrm{kHz}(1.2 \mathrm{~mm} \phi$ 搬送ケーブ ルによる X-60 方式), 時分割多重伝送方式の場合には 約 $100 \mathrm{Mb} / \mathrm{s}$ (新平衡ケーブルによる PCM-100 M 方式) が，現用中長距離伝送方式における最高伝送周波数であ る. ただし, ごく短距離用のものとしては, 前述のテレ ビ電話ベースバンド伝送方式として, $4 \mathrm{MHz}$ までの信号 伝送を行なっている例がある.

この漏話という欠点を改善したものが同軸ケーブルで これにより伝送周波数帯域幅は一段と拡大された。同軸 ケーブルによる信号伝送の場合, 帯域を制限するものは 雑音と伝送モードである．同軸ケーブルによる振幅変調 周波数多重分割伝送方式では, 熱雑音とひずみ雑音の総 和が回線規格を満足するよう設計されるが，中継間隔を 変化させた場合総合雑音值が最小之なる点があり，乙れ より最高伝送周波数が定まる. 図 $5^{9)}$ は同軸ケーブル中 心導体径亡最高伝送周波数の関係を求坛もので, 同図 右上りの直線がてれを示している.

つぎに伝送モードについてみると，同軸ケーブルによ る信号伝送では一般に TEM 波を基本モードとしている が, 伝送帯域を拡張して波長が短くなるとほかのモード が発生し, 信号伝送が不可能となる. 図 5 の右下りの直

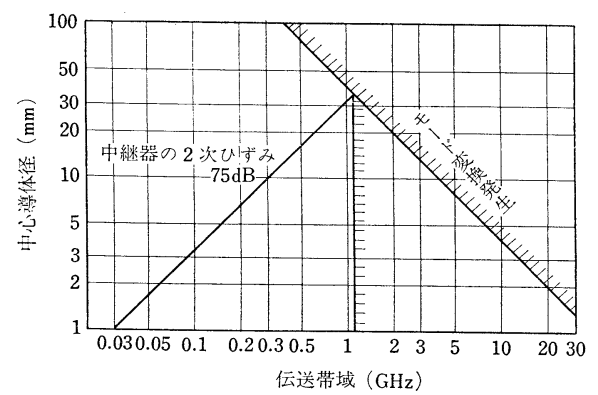

図 5 同軸方式の多重化の限界

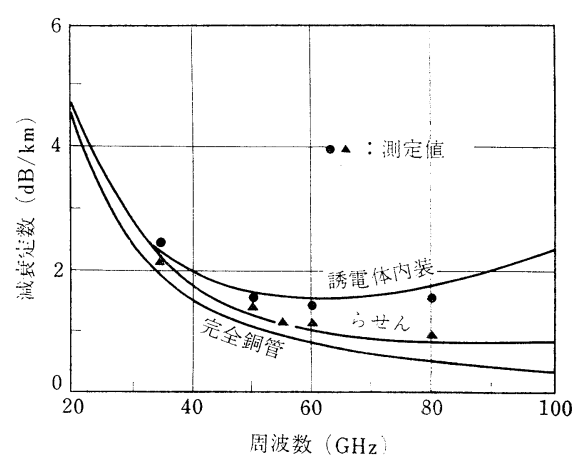

図 6 直線状らせんおよひ誘電体内奖導波管の減衰定数 (くい違い $50 \mu \mathrm{m}$, 折れ曲り $0.3 \mathrm{mrad}$ )

線はこの原因にもとづく最高伝送周波数の限界を示した むのである.したがって，同軸ケーブルによる周波数分 割多重伝送の場合には，同図の 2 直線に团まれた領域を 利用するととができる、ディジタル伝送の場合には，ひ ずみ雑音による影響は受けないので，モード变換による 制限のみから最高伝送周波数が定まる.

上述のように同軸ケーブルは, 図 5 に示すような潜在 的な伝送能力を有するが, 現在までのところでは周波数 分割多重伝送方式に上る帯域幅約 $60 \mathrm{MHz}$ の方式が実用 化されており ${ }^{10)}$,さらに $200 \mathrm{MHz}$ 帯域を放らって研究 が進められている。一方, 時分割多重伝送方式では, 400 $\mathrm{Mb} / \mathrm{s}$ の信号伝送を目標に研究が進められている.

ミリ波導波管伝送路としては, 内径 $51 \mathrm{~mm}$ の $\mathrm{TE}_{01}$ モード円形導波管が, 長距離伝送線路として研究されて いる. $\mathrm{TE}_{01}$ モードの減衰定数は周波数の $3 / 2$ 乘に逆比 例して小さくなるため, 理論的には伝送带域幅は無限大 であるといえるが，導波管線路の不完全性，たとえば曲 り,うねり, コーナ, 接続部くい違い等のために $\mathrm{TE} E_{01}$ モードの電磁界が崩れ, 不要モードが発生し損失が増加 する. 図6 は円形導波管線路の減衰特性で, 現在 40〜 $80 \mathrm{GHz}$ が带域として使用されている11.

空間を伝送媒体とする無線伝送路の場合は，利用しう る带域幅が先に与えられているので, この帯域幅をいか に効率よく利用するかが研究課題となる.

\section{（2）アナログ変調方式}

つぎに, テレビ電話信号の変調方式について検討して みよう、まず周波数分割多重伝送方式では，振幅変調方 式 (AM) と周波数変調方式 (FM) が考えられる. AM の場合には普通, 帯域の有効利用をはかるため単側帯波 (SSB) 方式が用いられるが，テレビ電話の場合には比帯 域が大きく，信号の中にきわめて低周波の成分が含まれ ており, SSB 信号を得るためには急峻な減衰特性をむつ 沪波器を使用せねばならず, その際に生ずる位相ひずみ を補償することが困難なので, 残留側带波 (VSB) 方式 が用いられる12)。 


\section{2. 電子画像システム}
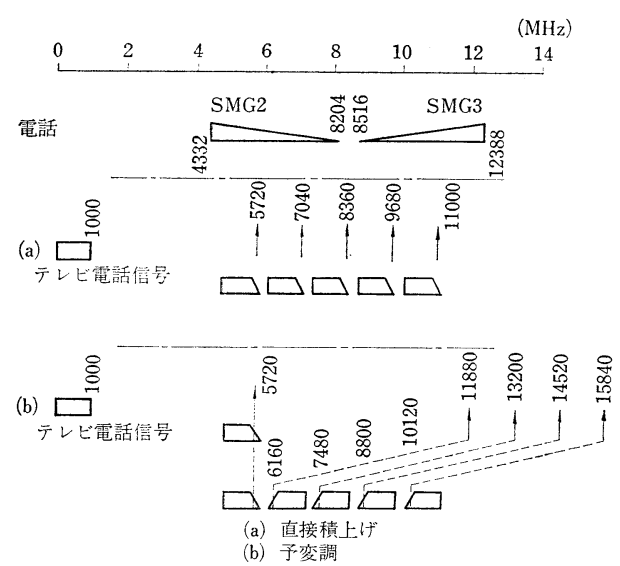

図 7 テレビ電話周波数配置案 (2SMG内 5 チャネル)

VSB 方式江いて，復調側で正しい波形を再生する ためには，復調用搬送波の位相を变調用搬送波の位相に 正しく合わせ齐ばならず，自動位相追尾回路が必要とな る.これに対し従来より各種回路が用いられているが， 大別するとパイロット信号その他を用い，乙れにより復 調用搬送波を得る方法と，ビデオ信号の同期部分を利用 して復調搬送波の位相を制御する方式とにわけることが できる。

前者は，入力信号がいかなる形のあのであってもてれ を伝送できるが，後者の場合は同期信号をもつ波形でな ければ伝送できないという制約を受ける，ただし，経済 的には後者のほうがはるかにすぐれている，両者の中間 の方式として，同期波形を有する信号が入ってきたとき はVSB，同期信号のない波形が入ってきたときにはSSB に切換える方式す検討されている. AMVSB 方式は，同 軸ケーブルによるFDM 方式に採用されている．図7は C-60M 方式による $1 \mathrm{MHz}$ テレビ電話信号伝送のため の周波数配置図で, 本方式によれば 1 システムでテレビ 電話信号 $30 \mathrm{ch}$ 分を多重化して伝送することができる.

伝送品質の点では, ビデオ 3 リンク， $2,500 \mathrm{~km}$ まで の伝送が可能である ${ }^{13}$ が，図 3 亿も示したように，将来 はビデオリンク接続の必要があるので，位相ひずみ特 性, レベル变動特性等を改良し伝送帯域幅む $200 \mathrm{MHz}$ 程度に広げた方式の研究が行なわれている。

FM 方式は AM 方式に比して帯域占有幅が広がると いう欠点を有しているが，刘雑音特性が良いため，フェ ーディングその他の原因により雑音の発生しやすいマイ クロ波無線中継方式における電話㧍よび放送テレビの中 継伝送には，むっぱらFM方式が用いられている。しか し，テレビ電話信号の伝送に対しては，FM 方式はわず かにマイクロ波下部帯域伝送方式として採用されている に過ぎない。

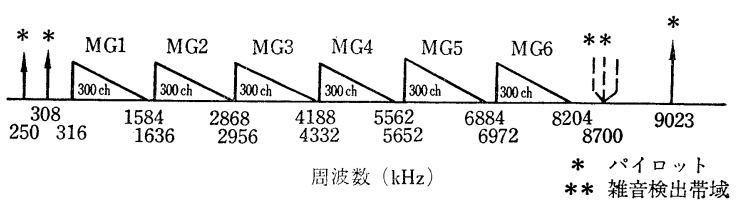

図 $86 \mathrm{GHz}$ 方式ベースバンド周波数配置

図 8 は $6 \mathrm{GHz}$ 方式ベースバンド周波数配置を示すむ はであるが，ここで多重電話回線用の MG1 (電話 300 ch 伝送用）を取除くと，直流加弓約 $1.58 \mathrm{MHz}$ までの 帯域があく.ここに $1 \mathrm{MHz}$ テレビ電話信号を挿入すれ ば， 1 無線 ch によりテレビ電話 $1 \mathrm{ch}$ と音声電話 1,500 ch が伝送可能となる. 本方式はテレビ電話導入初期に 抢ける伝送方式として期待されている ${ }^{14)}$.

\section{（3）ディジタル変調方式}

ディジタル変調方式としては各種の符号化方式が検討 されているほか，帯域圧縮方式の研究す盛んに行なわれ ている ${ }^{334)}$. 符号化方式㧍よび帯域圧縮方式決定の際, 検 討しなければならない点として，

(1) 中継伝送路技術の進歩により，その経費がきわめ て安価になるであ万う将来に扔いても, 経済的な通 信網を構成できるような方式であるか

(2) その方式を用いた場合，利用者が満足する良好な 画像品質を保証し得るか

(3) PCM 多次群構成の際のハイヤラーキーのひとつ として適当加

の 3 問題がある.中継伝送路経費はより大きな多重化， 光通信路などの新らしい伝送媒体を用いる方式の実用化 等により格段に低減できる可能性があるが, 符号器, 復 号器については一度決定した方式を変更するととは困難 で，製作技術，部品の進歩などによるわずかな経費の低 減はあるとしても，大幅な経済化は期待薄である．大幅 な帯域圧縮を可能にする方式は現時点ではきわめて高価 であり，当面簡単な符号化方式を採用せざるを得ないの で，将来，帯域圧縮方式を採用するとしてあ，乙れら簡 単な符号化方式と両立性を有する方式である必要があ る.

市外回線経費を $V$ ，伝送路経費を $1 \mathrm{Mb} / \mathrm{s} \cdot 1 \mathrm{~km}$ あたり $T$, テレビ電話信号を送るのに必要なビット速度を $k$ $\mathrm{Mb} / \mathrm{s}$ ，伝送路長を $x$ ，端局経費を $f(k)$ とすれば，

$$
V=f(k)+k x T
$$

となる， $k$ の值は画品質（符号化装置の特性）から，ま た $T$ は伝送方式により定まる。 $x$ は市外回線の平均長 を用いればよく，とれはテレビ電話のトラフィック状況 によって定まるが，ほぼ $200 \mathrm{~km}$ 程度といわれている. $f(k)$ は $k$ に対して減少関数となる. $f$ および $T$ の 推定は困難であるが，大胆な仮定のもとに各種方式につ 


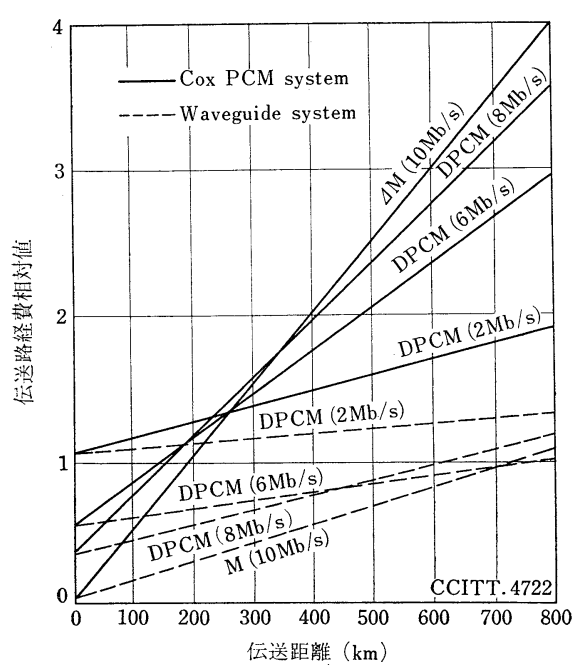

図 9 伝送路経費

き試算した結果を図 9 亿示す ${ }^{15)}$.

PCM 方式は信号波形の標本值を符号化する方式で, テレビ電話信号帯域を $1 \mathrm{MHz}$ とした場合，標本化周波 数は約 $2 \mathrm{MHz}$ となる. 符号化ビット数を少なくすると 量子化雑音が目立つので，6〜 7 ビット程度の符号化ビ ット数が用いられている. DPCM 方式は信号波形の標 本值之隣接標本值の差を符号化する方式であるが，原理 的に見て特性が信号の性質により大きく影響を受け，画 像信号のように相関の強い信号に対しては PCM 方式よ りもすぐれた特性が得られ，伝送帯域幅を節約できる可 能性がある.

また $\Delta \mathrm{M}$ 方式は比較器, パルス変調器, 積分器等の 簡単な回路で符号器, 復号器を構成できるため, 古くか ら研究されている. 符号化による画質劣化としては, 量子 化雑音, 偽輪郭, エッジビジネス, 勾配過負荷雑音等, アナログ方式とは異なった現象があらわれ，符号化方式 の種類によってもまた劣化の仕方が異なる．乙れらを相 互比較することは，なかなか困難であるが，図 10 に 1 $\mathrm{MHz}$ テレビ電話の信号を各種符号化方式に通した場合 の画像品質を示す ${ }^{-16)}$. 図の縦軸は平均評点で, 各数字は 下記カテゴリー ${ }^{17)}$ に対応する.

5. 画質劣化がまったく認められない.

4. 画質劣化はわずかに認められるが妨害とはならない.

3. 画質劣化が認められ，わずかに妨害となる.

2. 妨害となる.

1. 非常に妨害となる.

なお，図中で同期としてあるのは，標本化周波数をテ レビ電話信号の水平同期周波数の整数倍に同期させた場 合のデータである. 平均評点 4 以上を得るためには, $\mathrm{DPCM}$ 同期でクロック周波数 $8 \mathrm{MHz}$ 以上, DPCM 非 同期， $\Delta \mathrm{M}$ で $10 \mathrm{MHz}$ 以上, $\mathrm{PCM}$ 同期で $11 \mathrm{MHz}$ 以

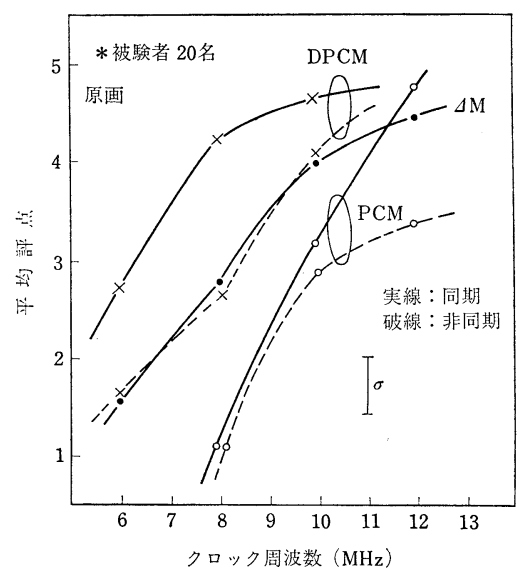

図 $10 \mathrm{DPCM}, \Delta \mathrm{M}, \mathrm{PCM}$ の品質比較

上を必要とする. 平均評点 3 でよければ，クロック周波 数は約 $1.5 \mathrm{MHz}$ 少なくてすむ. ただしてれはビデオ 1 リンクの区間を通したときの品質であり，実際には図 3 にも示すように最大 7 リンク構成となる可能性むあるの で，その場合には DPCM で $12 \mathrm{MHz}$ 以上， $\Delta \mathrm{M}$ で 16 $\mathrm{MHz}$ のクロック周波数が必要となってくる2).

上述のように，テレビ電話信号のディジタル伝送方式 について各種の検討が進んでいるが，超高速 PCM 伝送 路として実用されているあのがないため, 実際にテレビ 電話信号をディジタルで送っている例は少ない，乙こで は実験的に使用されている $2 ， 3$ の例をあげてみたい.

PCM-100 M 方式は, $1.2 \mathrm{~mm}$ 径の PEF 絶縁平衡対ケ ーブルを通して，クロック速度 $97.58 \mathrm{Mb} / \mathrm{s}$ のパルスを 伝送する方式で, 電電公社の武蔵野電気通信研究所之日 比谷本社の間を結ぶ実験回線として使用されている ${ }^{18)}$.

$1 \mathrm{MHz}$ テレビ電話信号伝送用に, $12 \mathrm{Mb} / \mathrm{s}$ の $\Delta \mathrm{M}$ 方式 および標本化周波数約 $2.4 \mathrm{MHz}$ ，符号化ビット数 5 の DPCM 方式とを備えている. 有線伝送路を用いる方式 としてはこのほかに，同軸ケーブルによるよりクロック 速度の早い方式が検討されているが，実用には供せられ ていない。

無線 PCM 万式としては，武蔵野電気通信研究所と荻 城電気通信研究所を結ぶ $2 \mathrm{GHz}$ 帯ディジタル中継実験 回線がある. $2 \mathrm{GHz}$ 带は $2.11 \mathrm{GHz}$ から $2.3 \mathrm{GHz}$ まで を用い，6無線 ch がとれるが，乙の実験回線では 2122.5 $\mathrm{MHz}$ および $2213.5 \mathrm{MHz}$ により， $64 \mathrm{Mb} / \mathrm{s}$ のパルス伝 送を行なっている．すなわち $16 \mathrm{Mb} / \mathrm{s}$ のパルス列 2 系列 により 4 相位相変調を行ない $32 \mathrm{Mb} / \mathrm{s}$ の伝送を実施して いるが，さらに，水平偏波と垂直偏波を利用するととに より $64 \mathrm{Mb} / \mathrm{s}$ の伝送容量を得ている ${ }^{18)}$. 本方式では, 1 $\mathrm{MHz}$ テレビ電話信号は標本化周波数 $2 \mathrm{MHz} \times$ 符号化ビ ット数 $7=14 \mathrm{Mb} / \mathrm{s}$ の PCM 信号として伝送されている. 


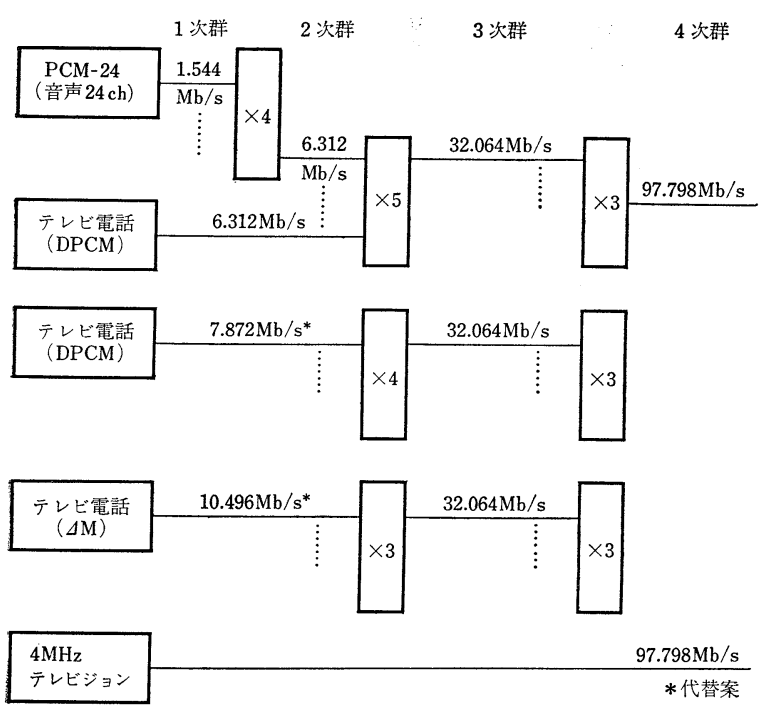

図 $11 \mathrm{PCM}$ ハイヤラーキー案

また $4 \mathrm{MHz}$ テレビ信号はビット速度 $30 \mathrm{Mb} / \mathrm{s}$ の $\Delta \mathrm{M}$ 信号として伝送されている.

ミリ波導波管通信方式関係では，茨城電気通信研究所 々水戸報話局の間約 $23 \mathrm{~km}$ の区間で実験が行なわれて いる. この方式は $43 \sim 87 \mathrm{GHz}$ の周波数帯域を A, B, C, $\mathrm{D}$ の 4 周波ブロックに分割して $\mathrm{A} \cdot \mathrm{B}$ をり，C·Dを下 りに用いて，1 本の円形導波管で双方向伝送を行なうも のである. 各周波数ブロックにはおのおの 13 個の搬 送波を配置し，各搬送波ごとに4 相位相変調により約 $800 \mathrm{Mb} / \mathrm{s}$ のディジタル符号を伝送している ${ }^{19)}$.

PCM 方式のハイヤラーキーについては, 音声伝送の 立場から種々の検討がなされているが，今後はテレビ電 話をはじめ各種新サービス信号の伝送をむ考慮にいれて 検討する必要があ万う. 図 11 は八イヤラーキーの一案 で, 音声伝送の立場からは PCM 2 次群のビット速度を $6 \mathrm{Mb} / \mathrm{s}$ にしたいとの要請があり, 同期符号化 DPCM 方 式等がこの意味からは有望であろう.

\section{（4）ディジタル統合方式}

前節でビデオ 7 リクの伝送を行ない，しかす良好 な画像品質を得るためにはビット速度をかなり高くす る必要があるととを述べた。しかしながら，符号化さ れた信号を原信号の形に戻さずディジタル信号のまま で交換し受信端末ではじめて復号するようにすれば, 符号化, 復号化にと屯なう品質劣化の累積を避けるこ とができる，乙れがディジタル統合方式である．

ただし，一般に時分割多重 (TDM) 法送方式は独立 同期方式をとっているため，たとえば図 12 において $\mathrm{A}, \mathrm{B}$ 両集中局と中心局を結ぶ回線のディジタル信号 のクロック数は異なっている.したがって，中心局で これをパルス列の形のままで交換し，総括局へ向けて 多重化信号として送り出すためには，中心局に抢いて 何らかの手段により，両信号のクロックを同期させて やる必要がある。時分割多重化装置化用いられる同期 方式のひとつにパルススタッフ同期方式がある. 本方 式は, 多重化装置隹入力する信号の速度よりも出力信 号のディジタル速度を高くとって扔いて，同期をとるた めに余分のパルスを挿入付加する方法である ${ }^{20)}$.

また別の方式として，平衡相互同期方式がある ${ }^{21)}$. こ れは各局にそれぞれ独自のクロックを怙き，てのクロッ ク周波数がその局に入ってくるすべての入力周波数の平 均値になるように設定する方式である，したがって，網 の一部に障害があっても全体に影響は及ばないという特 長を有する. しかし, 網が小数局から大規模なむのへと 発展したときの問題とか, システム全体を安定に衔かす ためにはどうすべきか等の点で，今後とも研究を要する といわれている.

さらに, 最近提案されている方式として, 準同期方式 ${ }^{22)}$ がある. センターに基準クロックを設け, 従属局ではこ れをうけてクロック同期回路を働かし，その出力により さらに下位の局の制御を行なう方式である.クロック分 配系に障害が生じれば従属局の発振器は自走するよう

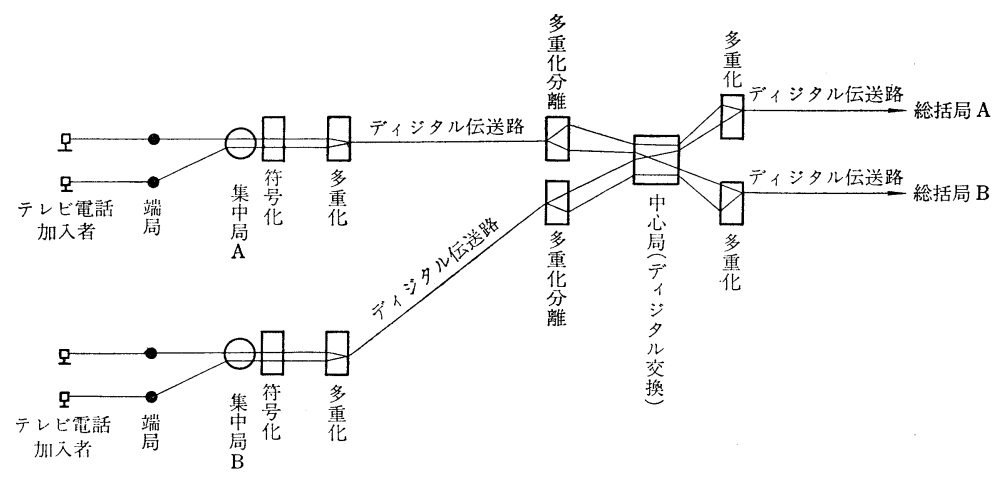

図 12 ディジタル統合方式 


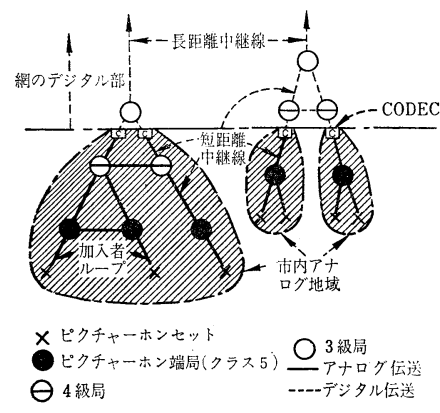

図 13 ピクチャホン網

になっている．自走時の発振周波数確度を $10^{-7}$ とすれ ば，同期崩れにもとづくパルス哉失あるいは余剩パルス の插入等は $1 \sec に 1 \sim 3$ 回程度となり，画品質が劣化 する.クロック分配系をできるだけ網状構成とすれば障 害時間率を小さくできる.

よ゙の同期方式がすぐれているかは経済性，品質等，考 慮すべき要因が多く，現段階ではきめがたい.

これらの技術を用いた，ディジタル統合網の一例を 図 13 に示す。これはATTにより提案された方式で, 網はアナログ部とディジタル部に大別されており，全国 主要都市を結ぶディジタル網は 1970 年代の後半に実現 される予定である.

わが国においては，テレビ電話サービスはようやくそ の緒についた段階であり，将来の通信をディジタル網と するかアナログ網とするかは目下検討中であり，将来有 望と見られる方式について，幅広く研究が行なわれてい る.

\section{4. 静止画像通信網による画像情報の伝送}

テレビにおいては動きの不連続による不自然さをなく し，ちらつきを減らすために，1 secに30 枚の画像を 伝送している。しかし，むともと動きのない書画やスラ イド等を伝送する場合には，1 sec に伝送する画像枚数 を減らしても動きの不自然さはなく，伝送経費を格段に 安くすることができる.

そのひとつとして静止画放送の構想が NHK より発表 されている ${ }^{23)}$. 本方式では，1つの番組に対し，たとえ ば $10 \mathrm{sec}$ に 1 回の割合で画像を送るとすれば, $10 \mathrm{sec}$ 当り 300 種の画像の伝送が可能になるととを利用してい る.すなわち, 每フレーム違った画像を伝送し, 受信側で は各フレームにつけられた識別番号によって番組を識別 してそのフレームをとり出し, アダプターを介して, 通常 のテレビモニター上に表示させようという方式である.

このような静止画像伝送方式は放送以外にも適用分野 が多く, テレビ電話網を通してフレームごとに内容の異 なる静止画像伝送を行なおうという提案屯ある ${ }^{24)}$. また
テレビ電話のオプションとして，送信側で走査を低速走 査に切換え, 走查線数を 1,000 本以上に増加して精細画 像を伝送しようという試みあある25).

これらの方式で取报われる信号は，いずれも数百 $\mathrm{kHz}$ からビデオ帯域にわたる周波数成分を有しており，静止 画像放送の場合は別として，それ以外の情報はこれを独 立の通信網によりサービスするよりも，テレビ電話中継 網を通して伝送するのが有利と考えられる，その場合 に，信号の性質に起因するいくつかの問題点が生ずる が，それについて簡単に考察してみたい。

\section{1 ディジタル変調方式}

テレビ電話信号をディジタル変調する場合，信号の性 質を利用しできるだけ少ないビット速度で通信を行なお うとしている. DPCM, $\Delta \mathrm{M}$ では信号標本值間の相関を 利用しており，PCM 方式に比してかなりの帯域压縮効 果がある．静止画像でもテレビ電話信号と同じ性質をむ っている信号に対しては圧縮効果が期待できる。しかし 低速走查による精細画像伝送のような場合にはこれがあ てはまらず，高々最高伝送周波数 $500 \mathrm{kHz}$ 程度の信号 しか伝送できない。また，フレーム間相関を利用した帯 域王縮方式は，フレームごとに異なった静止画像を伝送 できないのは当然で，この方式の採用可否については今 後とも慎重な検討を必要としよう.

\section{2 アナログ変調方式}

AMVSB 方式として，テレビ電話の同期信号を用い て復調用搬送波の位相制御を行なう方式では，同期信号 をむたない形の静止画像信号が入ってきたときは伝送不 可能となる．乙れを解決する方法として，パイロット等 を用いる位相制御方式を採用すればよいが，乙の方式は 経済性の点で劣るという欠点を有する．乙れを防ぐ意味 で図 14 亿示す VSB・SSB 切換え方式を採用すると， $\mathrm{SSB}$ 方式に切換わったとき直流伝送ができなくなる. 直流伝送するためには図 15 に示すように，あらかじめ 端末で変調をかけておく必要がある。

しかるに前節に述べたように， $\triangle \mathrm{M}, \mathrm{DPCM}$ 等の方式 では高々 $500 \mathrm{kHz}$ 程度の信号伝送しかできないため, 1 つの通信網の中にアナログ変調方式とディジタル変調方 式が混在する場合には，端末から伝送する信号の最高周 波数は $500 \mathrm{kHz}$ 程度に押える必要がある. この制約か ら，端末に打ける变調用搬送波の周波数は $250 \mathrm{kHz}$ 以上 に選定できなくなり伝送可能な最高周波数屯約 $250 \mathrm{kHz}$ となる。

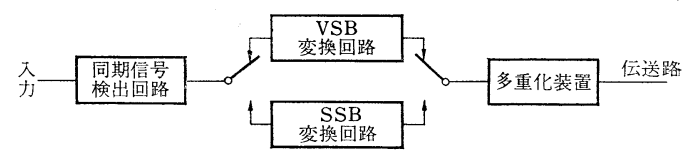

図 $14 \mathrm{VSB} \cdot \mathrm{SSB}$ 切換方式 


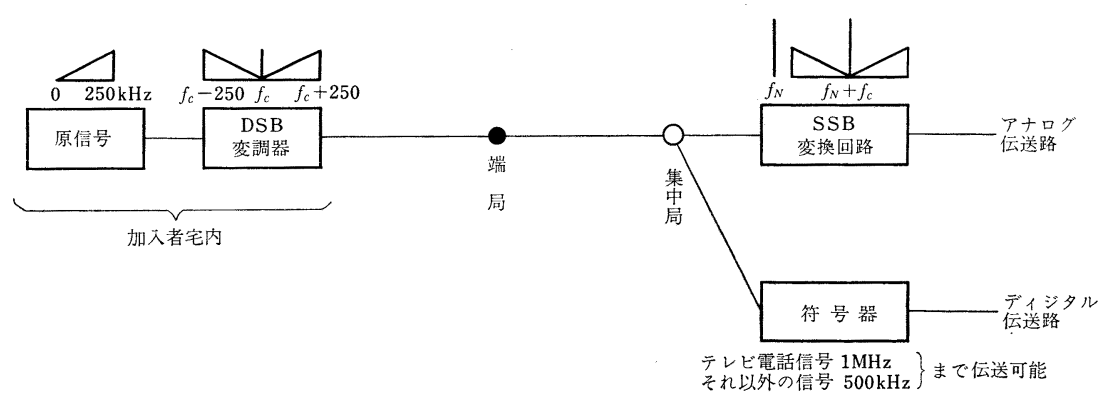

図 15 アナログ・ディジタル混合網による画像情報伝送

以上を要約すると，テレビ電話と静止画像とを同一の 通信網で伝送する場合には，テレビ電話信号としては約 $1 \mathrm{MHz}$ までの信号伝送, それ以外の形の静止画像信号と しては約 $250 \mathrm{kHz}$ までの信号伝送が可能となる.なお， テレビ電話用にフレーム間相関を用いた带域圧縮方式を 用いた場合には，伝送し得る静止画像の最高周波数はさ らに小さくなる.

\section{5.むす び}

以上，画像情報の伝送システムにつき，テレビ電話伝 送方式を中心に説明を行なった．ただ最近における画像 工学の発展に対応して, 画像情報伝送システムについて 本誌をはじめ各種学会誌，技術雑誌にいくつかの解説が でているので，乙れらと重複しないよう，経済的な考察 むとりいれて，できるだけユニークな解説を行なうよう つとめた. CATV, ファクシミリ，テレビ帯域圧縮伝送 方式等については，意識して重複をさけたので，巻末の 文献を参照して技術的な点を補なっていただけたらと思 っている.

(昭和 47 年 7 月 18 日受付)

\section{〔参考 文 献〕}

1) 林 龍雄: テレビジョンの新応用, 電気書院 (1965) 9

2) 麻生 哲：ファクシミリ伝送方式，テレビ誌，26，4 (1972) 300 $-307$

3 ）南 敏: 新サービス情報伝送方式，テレビ誌，25，6 (1971) $434-445$

4 ） 福島邦彦: テレビジョン信号の帯域圧縮，信学誌，53，3 (1970)
$332-344$

5) 大森 喬: 画像通信にお污る帯域圧縮の現状, 第 2 回画像工学コ ンファレンス凟料 2-1 (1971)

6）石原藤夫：分岐加入者路線の新サービス信号に対する適応限界に ついて，通研実報，19，4（1970）903-920

7) J.M. Brown: Baseband Video Transmission on Loops and Short-Haul Trunks, BSTJ, 50, 2 (1971) 395-425

8 ) 日本電信電話公社：電気通信自主技術開発史(搬送電話編) (1972) 631

9）熊谷伝六: 有線通信の変ぼう, 通研実報, 17，9 (1968) 17231743

10）熊谷伝六：C-60M方式，通研実報，20，5（1971）1039-1040

11）小口文一：ミリ波通信方式の研究，通研実報，16，8(1967) 1437 $-1485$

12）森下智二ほか：カラーテレビジョン映像変换装置の実用化，通研 実報, 20，5 (1971) 1219-1246

13）森下智二ほ加：テレビ電話映像変換装置の設計，通研実報，20， 10 (1971) 2231-2254

14）矢野常俊ほか：東京〜大阪間テレビ電話伝送試験結果報告，施設， 22, 9 (1970) 119-124

15) CCITT, SpD, TD-2: Encoding and Decoding Method for Visual Telephone Signals (1971)

16) 小林幸雄：テレビ電話画像品筫の評価，信学会画像研資 (1972年 8 月発表予定)

17) CCIR: Subjective Assessment of the Quality of Television Pictures, Report 405-1-New Delhi (1970)

18）通研月報， 25，6（1972） 12-19

19）通研月報，25，1 (1972) 8-13

20) 庄司茂樹好監訳：伝送システム, ラテイス社 (1971) 685-687

21）大和淳二ほ汃：PCM 交換に括斿る平衡相互同期，通研実報，16, 10 (1967) 2013

22）近藤昭二ほか：準同期ディジタル通信網の提案，信学会方式研資， CS 71-96 (1971)

23）山根久吉ほか：静止画像実験システム，NHK 技研月報，15，1， (1971) $12-17$

24) 大和淳二ほか：静止画像伝送網の構成法, 昭47年信学全大予, No. 1529

35）大久保栄ほか：テレビ電話用精細画像送信装置に関する実験，昭 47年信学全大予, No. 1763 